\title{
A Study on Evaluation of Nutritional Status in Patients with Chronic Obstructive Pulmonary Disease
}

\author{
Sahithi Reddy Challa ${ }^{1}$, Abdul Rafi Shaik², Manasa Reddy Musku³ \\ ${ }^{1}$ Department of Pulmonary Medicine, Maven Medical Centre, Hyderabad, Telangana, India. ${ }^{2}$ Department of \\ Pulmonary Medicine, Shadan Institute of Medical Sciences \& Research Centre, Hyderabad, Telangana, India. \\ ${ }^{3}$ Department of Pulmonary Medicine, Osmania Government and General Chest Hospital, Hyderabad, \\ Telangana, India.
}

\section{ABSTRACT}

\section{BACKGROUND}

Currently, chronic obstructive pulmonary disease is the fourth leading cause of death in the world. Nutritional depletion is a common finding in patients with COPD (Chronic Obstructive Pulmonary Disease). Even stable COPD patients have high proportion of under nutrition. Malnutrition is an important factor that leads to low quality of life in COPD patients and could cause exacerbation of the disease. Hence malnutrition needs to be assessed and considered in management of COPD.

\section{METHODS}

A cross sectional study was conducted over a period of 2 years to determine the association of COPD with malnutrition. 50 male COPD patients between 40 to 60 years of age fulfilling the inclusion criteria were selected, and the analysis was restricted to this age group, so as to ensure the uniformity of analysis. They were staged based on PFT and evaluated by anthropometric measures and biochemical parameters. Statistical analysis was done and $\mathrm{p}<0.05$ was considered statistically significant.

\section{RESULTS}

In this study the average age of the population was $52.52+5.64$ years. 50 male COPD patients were categorized into mild $(n=10)$, moderate $(n=27)$, severe $(n=10)$ and very severe $(n=3)$ groups with spirometry based on GOLD criteria. Anthropometric measures (BMI, TSF, MAMA, MAFA) and biochemical parameters (serum albumin and pre-albumin) were evaluated. The difference in severity of airway obstruction, body weight, BMI, pre-albumin and serum albumin among the various age groups was not significant statistically. There was a significant difference $(\mathrm{p}<0.05)$ in BMI, MAMA, MAFA, pre-albumin and serum albumin values in severe and very severe airway obstruction patients when compared to those with mild and moderate airway obstruction. The present study showed a statistically significant and strong correlation of BMI (i.e. $r=0.75$ and $p<0.05)$, MAMA ( $r=0.81$ and $p<0.05)$, MAFA ( $r$ $=0.72$ and $\mathrm{p}<0.05)$, serum pre-albumin $(\mathrm{r}=-0.315$ and $\mathrm{p}=0.006)$, and albumin $(\mathrm{r}=$ $0.74)$ when compared with severity of airway obstruction.

\section{CONCLUSION}

A significant number of patients with Chronic Obstructive Pulmonary Disease was malnourished. Measures of protein stores (serum albumin and pre-albumin) and the anthropometric measures of nutrition [BMI, body muscle mass and fat stores] were inversely related with severity of airway obstruction.

\section{KEY WORDS}

COPD, BMI, PFT, TSF, MAMA, MAFA, Serum Albumin, Pre-Albumin

\author{
Corresponding Author: \\ Dr. Abdul Rafi Shaik, \\ Associate Professor, \\ 612, Mahara Block, \\ Garden Towers, Masab Tank, \\ Hyderabad - 500028, \\ Telangana, India. \\ E-mail: rafpulm@gmail.com
}

DOI: $10.14260 /$ jemds/2020/840

How to Cite This Article:

Challa SR, Shaik AR, Musku MR. A study on evaluation of nutritional status in patients with chronic obstructive pulmonary disease. J Evolution Med Dent Sci 2020;9(51):3828-3832, DOI: $10.14260 / \mathrm{jemds} / 2020 / 840$

Submission 13-06-2020,

Peer Review 28-10-2020,

Acceptance 05-11-2020,

Published 21-12-2020.

Copyright (C) 2020 Sahithi Reddy Challa et al. This is an open access article distributed under Creative Commons Attribution License [Attribution 4.0 International (CC BY 4.0)] 


\section{BACKGROUND}

"Chronic obstructive pulmonary disease (COPD) is the fourth leading cause of death in the world.1" Globally the COPD burden is predicted to increase in coming decades because of aging of the population and continuous exposure to COPD risk factors. "Major cause of chronic morbidity and mortality

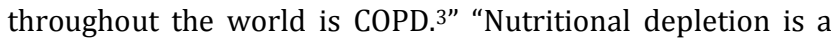
common finding in patients with COPD. Stable COPD patients also had high proportion of under nutrition. $4^{\prime \prime}$

Malnutrition is the most important factor that leads to low quality of life in COPD patients and contributed to the exacerbation of disease. ${ }^{5}$ Most of the patients with severe COPD are lean, and in a malnourished or under nourished state referred to as pulmonary cachexia syndrome, characterized by loss of fat free body mass causing wasting of muscles. It is estimated to occur in 25 to $40 \%$ of COPD patients and is associated with a decline in functional status, carry an unfavourable prognosis.6-8 The wasting of muscles in COPD patients not only leads to decreased skeletal muscle function leading to reduced exercise capacity, is also a major determinant of mortality in COPD, independent of airflow obstruction. Nutritional supplement therapy has been incorporated in the management of COPD since a long time and has shown promising results. ${ }^{9}$ The exact cause for malnutrition remains unclear in COPD patients, as multiple factors like tissue hypoxia, disuse atrophy, changes in metabolism and calorie intake, oxidative stress, aging, inflammation and medications (glucocorticoids) contribute to a progressive reduction in lean body mass. To assess the severity of malnutrition, biochemical parameters that reflect the visceral protein levels in the body are also used.

\section{Objectives}

1. To determine the association of Chronic Obstructive Pulmonary Disease and malnutrition.

2. To determine the association between severity of airflow obstruction and malnutrition.

3. To evaluate as to whether the biochemical markers of protein stores (serum albumin and prealbumin) correlate with the severity of airflow obstruction.

\section{METHODS}

This was a simple, cross-sectional study conducted in the department of Pulmonary Medicine, for a period of 2 years at MNR Medical College and Hospital, Sangareddy. The subjects who consented for the study were taken and was approved by the Institutional Ethical Review Board. 50 patients who fulfilled the inclusion \& exclusion criteria were selected.

\section{Inclusion Criteria}

Male COPD patients between age group of 40 to 60 years.

\section{Exclusion Criteria}

- Patients with exacerbation of symptoms less than 2 months prior to study.
- Patients with comorbidities like diabetes mellitus, cor pulmonale, bronchial asthma, tuberculosis and HIV.

- Critically ill patients and those patients who were not able to perform spirometry.

- Patients on oral corticosteroids.

- Patients with other related diseases which will affect the nutritional status e.g. liver cirrhosis, bronchiectasis and cystic fibrosis etc.

- Non-smokers.

\section{Method of Data Collection}

Patients were defined as having COPD supported by GOLD (Global Initiative for Obstructive Lung Disease) criteria. To make sure the uniformity of research, the study was restricted to patients between the age group of $40-60$ years. BMI was calculated and TSF (Triceps Skinfold Thickness) thickness of the non-dominant arm was measured by employing a vernier calipers. ${ }^{10}$ Mid arm circumference was measured with a standard measuring tape. Nutritional Indices were calculated using the below standard formulae ${ }^{4}$

Mid Arm Muscle Circumference $=$ MAC $-(3.14 \times$ TSF $)(\mathrm{cm})$.

Mid Arm Muscle Area (MAMA) $=(\text { MAMC })^{2} / 4 \times 3.14$

(MAMA) $\left(\mathrm{cm}^{2}\right)$

Mid Arm FAT Area (MAFA) $=\left[\mathrm{MAC}^{2} /(4 \times 3.14)\right]-$ MAMA

(MAFA) $\left(\mathrm{cm}^{2}\right)$

FAT $/$ Muscle Index $=$ MAFA $/$ MAMA

\section{Laboratory Investigations}

Serum pre-albumin was measured by using standard immunoturbidimetric method. This provides reference value of $16-40 \mathrm{mg} / \mathrm{dL}$. Serum albumin sample was measured using spectrophotometric method. This gives reference value of 3.5 - 5.5 gm / dL or 35 - 55 gm / litre. For every patient, detailed medical record was taken and clinical examination was done. On the study day, weight and height of the patients were recorded.

\section{Statistical Analysis}

The information was processed and analysed using SPSS software version 25.0 for windows and Microsoft excel. All data were analysed using descriptive analysis. For the comparison of variables with in the two independent groups, unpaired t-test was used. The difference among more than two groups were evaluated by one-way ANOVA (Analysis of variance). The relation between anthropometric indices and $\mathrm{FEV}_{1}$ was evaluated by Pearson's correlation. $\mathrm{P}<0.05$ was considered statistically significant.

\section{RESULTS}

We included 50 patients who were examined and evaluated. The difference within the severity of airway obstruction, weight, pre-albumin and albumin among the distinct age groups was not significant statistically. There was a 
statistically significant difference within the mean weight of patients in severe and very severe groups compared with mild and moderate groups.

\begin{tabular}{|ccc|}
\hline Parameter & Mean & Standard Deviation \\
Age & $52.52 \mathrm{yrs}$. & 5.64 \\
Weight (wt.) & $56.30 \mathrm{Kg}$ & 9.82 \\
Height (ht.) & $1.64 \mathrm{mts}$. & 0.07 \\
Mid Arm Circumference & $23.41 \mathrm{cms}$ & 3.74 \\
Triceps Skin Fold & $1.32 \mathrm{cms}$ & 0.28 \\
Body Mass Index & $20.76 \mathrm{Kg} / \mathrm{m}^{2}$ & 3.09 \\
Mid Arm Muscle Circumference (MAMC) & $19.25 \mathrm{~cm}^{2}$ & 3.01 \\
Mid Arm Muscle Area (MAMA) & $30.23 \mathrm{~cm}^{2}$ & 8.93 \\
Mid Arm Fat Area & $14.52 \mathrm{~cm}^{2}$ & 4.93 \\
Fat / Muscle Ratio & 0.47 & 0.07 \\
Pre-Albumin & $25.52 \mathrm{mg} / \mathrm{dL}$ & 7.09 \\
Albumin & $3.67 \mathrm{gm} / \mathrm{dL}$ \\
\hline FEV1 & $64.13 \%$ & 0.30 \\
\hline Table 1. Study Population Characteristics \\
\hline Most of them (68 \%) were within the age between 50 and 60 yrs. \\
\hline
\end{tabular}

\begin{tabular}{|cccc|}
\hline $\begin{array}{c}\text { Severity of Airway } \\
\text { Obstruction }\end{array}$ & $\begin{array}{c}\text { FEV }_{\mathbf{1}} \\
\text { (\% Predicted) }\end{array}$ & Number & $\begin{array}{c}\text { Percentage } \\
\text { (\%) }\end{array}$ \\
Mild & $>=80$ & 10 & $20 \%$ \\
Moderate & $50-79$ & 27 & $54 \%$ \\
Severe & $30-50$ & 10 & $20 \%$ \\
Very Severe & $<30$ & 3 & $6 \%$ \\
\hline \multicolumn{2}{|c}{ Table 2. COPD Severity (Based on FEV $\mathbf{1}$ ). } \\
\hline
\end{tabular}

\begin{tabular}{|cccc|}
\hline $\begin{array}{c}\text { Severity of Airway } \\
\text { Obstruction }\end{array}$ & $\begin{array}{c}\text { Mean BMI } \\
\left(\mathbf{K g} / \mathbf{~ m}^{2}\right)\end{array}$ & $\begin{array}{c}\text { Standard } \\
\text { Deviation }\end{array}$ & $\begin{array}{c}\text { One Way } \\
\text { ANOVA }\end{array}$ \\
Mild $(\mathrm{n}=10)$ & 23.80 & 1.63 & \\
Moderate $(\mathrm{n}=27)$ & 21.35 & 2.28 & $\mathrm{p}<0.0001$ \\
Severe $(\mathrm{n}=10)$ & 17.45 & 2.00 & Significant \\
Very Severe $(\mathrm{n}=3)$ & 16.34 & 1.23 & \\
\hline Table 3. Relation between BMI and Severity of Airway Obstruction \\
\hline
\end{tabular}

\begin{tabular}{|cccc|}
\hline $\begin{array}{c}\text { Severity of Airway } \\
\text { Obstruction }\end{array}$ & $\begin{array}{c}\text { Avg. MAMA } \\
\left(\mathbf{c m}^{\mathbf{2}}\right)\end{array}$ & $\begin{array}{c}\text { Standard } \\
\text { Deviation }\end{array}$ & $\begin{array}{c}\text { One Way } \\
\text { ANOVA }\end{array}$ \\
Mild $(\mathrm{n}=10)$ & 38.57 & 6.17 & \\
Moderate $(\mathrm{n}=27)$ & 32.11 & 6.47 & $\mathrm{p}<0.0001$ \\
Severe $(\mathrm{n}=10)$ & 21.05 & 5.14 & Significant \\
Very Severe $(\mathrm{n}=3)$ & 16.10 & 2.22 & \\
\hline
\end{tabular}

Table 4. Relation between Severity of Airway Obstruction and MAMA.

\begin{tabular}{|cccc|}
\hline $\begin{array}{c}\text { Severity of Airway } \\
\text { Obstruction }\end{array}$ & $\begin{array}{c}\text { Avg. Serum Pre- } \\
\text { Albumin }(\mathbf{m g} / \mathbf{d L})\end{array}$ & $\begin{array}{c}\text { Standard } \\
\text { Deviation }\end{array}$ & $\begin{array}{c}\text { One Way } \\
\text { ANOVA }\end{array}$ \\
\hline Mild $(\mathrm{n}=10)$ & 32.51 & 2.08 & \\
Moderate $(\mathrm{n}=27)$ & 27.33 & 5.10 & $\mathrm{p}<0.0001$ \\
Severe $(\mathrm{n}=10)$ & 16.74 & 3.15 & Significant \\
\hline Very Severe $(\mathrm{n}=3)$ & 15.30 & 0.72 & \\
\hline
\end{tabular}

Table 5. Relation between Airway Obstruction and Serum Prealbumin

There was a significant difference in BMI, MAMA, MAFA, pre-albumin and serum albumin values in patients with severe and very severe airway obstruction groups as compared to patients with mild and moderate airway obstruction groups.

Of the $13(26 \%)$ patients with severe and very severe airflow obstruction, 10 of them were within the bottom quartile of BMI, 9 patients were in the lower quartile of Midarm Muscle Area (MAMA) and 10 patients were within the bottom quartile of MAFA. Out of 50 total patients, 14 (28\%) were found to have a BMI less than $18.5 \mathrm{Kg} / \mathrm{m}^{2} .9$ (18\%) patients have albumin level of less than $3.5 \mathrm{gm} / \mathrm{dL}$.

\section{DISCUSSION}

Chronic obstructive pulmonary disease is the major public health concern and is often associated with significant nutritional abnormalities. Malnutrition can be harmful in patients with COPD which is due to reduced respiratory muscle mass and strength; decreased cell immunity, poor wound healing and decreased ventilatory response to hypoxia. ${ }^{11}$ Results of the study showed that most of the measured parameters in COPD patients decreased as the disease severity increased. These reductions were much in stage 3 and 4 of the disease. These findings confirm previous studies conducted on nutritional status in COPD patients and have shown that with increase in the severity of disease, the patients face a decline in BMI, muscle and fat mass and albumin levels. In this study, the average age of the population was $52.52+5.64$ years (Table 1 ). The patients in the present study were between 40 - 60 yrs. of age. This was done for the reason that $\mathrm{FEV}_{1}$ was found to steadily decrease as the age advances. To ensure the uniformity of analysis in the study, patients were selected within the narrower age group.

No significant difference was found in the severity of airway obstruction $\left(\mathrm{FEV}_{1}\right)$ and the biochemical parameters (serum albumin and pre-albumin) between the distinct age groups. As the pre-albumin values were found to vary between males and females; females have a lower value of pre-albumin, the patients in this study includes only males. Soler JJ et $\mathrm{al}^{4}$ study includes 177 (99.4\%) male and 1 (0.6\%) female patients. In the study by Mathew JT et al,12 included 25 patients, and all were male.

\section{Forced Expiratory Volume in the First Second (FEV 1 )}

The mean $\mathrm{FEV}_{1}$ of patients in this study was $64.13+18.33$ (percentage predicted) (Table 1). The population was divided into mild $(n=10)$, moderate $(n=27)$, severe $(n=10)$ and very severe $(n=3)$ airway obstruction based on GOLD criteria ${ }^{3}$ (Table 2). $\mathrm{FEV}_{1}$ did not differ significantly among the various age groups. Soler JJ et al, ${ }^{4}$ study established that malnutrition in stable COPD patients is the most common problem that increases as the severity of disease progresses. In the study by Chaudhary SC et al, 13 there was no statistically significant difference between the age and airway obstruction $\left(\mathrm{FEV}_{1}\right)$ of the disease.

\section{Anthropometric Measures}

Anthropometric assessment is used as it is an inexpensive and simple alternative for evaluation of the body composition.

\section{Weight}

The average weight of the present study population was 56.3 $+9.82 \mathrm{Kg}$. Body weight among different age groups of the patients was not significant statistically $(p=0.053)$. But there was a statistically significant difference in the body weight of patients among the different groups of severity of disease $(\mathrm{p}<$ 0.05). A significant and moderate positive correlation was found between the body weight of patients and severity of disease $(r=0.67$ and $p<0.05)$. "These findings are similar to the study done by Soler JJ et al4."

\section{Height}

The average height of the present study population was $1.64+$ $0.07 \mathrm{mts}$ (Table 1 ). 


\section{Body Mass Index}

The average BMI of the study population was $20.76+3.09 \mathrm{Kg}$ $/ \mathrm{m}^{2}$ (Table 1). According to WHO classification, BMI less than $18.5 \mathrm{Kg} / \mathrm{m}^{2}$ is considered as underweight in general population. ${ }^{14}$ This study demonstrated a correlation between severity of airway obstruction and lower BMI. 14 (28\%) patients have BMI of less than $18.5 \mathrm{Kg} / \mathrm{m}^{2}$. There was a significant difference in the mean BMI value between severe, very severe airway obstruction and the above two (mild and moderate) groups. This study also established a significant, strong and positive correlation between BMI and the severity of airway obstruction $\left(\mathrm{FEV}_{1}\right)$ (i.e. $r=0.75$ and $\mathrm{p}<0.0001$ ). Out of 50 patients, $13(26 \%)$ were in the lower quartile $\left(<25^{\text {th }}\right.$ percentile) of the study population. In the study by Sami et al,15 BMI had positive and significant correlation with $\mathrm{FEV}_{1}(\mathrm{r}=$ 0.27 and $p=0.020$ ). These findings are similar to the study done by Gupta B et al. ${ }^{16}$

\section{Mid Arm Circumference (MAC)}

In this study the mean midarm circumference was $23.4+3.74$ $\mathrm{cm}$. Anthropometric studies done by Matthews AL et $\mathrm{al}^{17}$ showed that a midarm circumference $<23 \mathrm{~cm}$ signifies undernutrition.

\section{Triceps Skinfold Thickness}

The mean TSF thickness in this study population was $1.32+$ $0.28 \mathrm{~cm}$. Though there are no particular standards, population studies (done by Robert JM et al ${ }^{18}$ ) have found a value of 0.9 $2.1 \mathrm{~cm}$. As TSF is highly affected by subcutaneous oedema and so may be reported higher than the real value, there is a lack of association between TSF thickness and disease severity. In the study conducted by Soler JJ et $\mathrm{al}^{4}$, TSF thickness was at or within the bottom quartile for $58(32.6 \%)$ patients.

\section{Mid Arm Muscle Area (MAMA)}

In this study the average MAMA of patients was $30.23+8.93$ $\mathrm{cm}^{2}$ (Table 1). 12 (24\%) patients who were in the lower quartile $\left(<25^{\text {th }}\right.$ percentile) of the distribution were found to have severe depletion in the muscle mass. A statistically significant difference was found in MAMA of patients with severe and very severe airflow obstruction when compared to those who have mild and moderate airway obstruction. But there was no significant difference between severe and very severe groups (Table 4). This study also showed a statistically significant and strong positive correlation between decrease in muscle mass and increase in severity of airflow obstruction ( $r=0.81$ and $p<0.0001)$. In the study by Soler JJ et al, ${ }^{4}$ also showed a significant correlation between midarm muscle area (MAMA) and $\mathrm{FEV}_{1}(\mathrm{r}=0.30$ and $\mathrm{p}<0.001)$. He established that muscle store was the compartment most often affected. This suggested that malnutrition induces to muscle wasting rather than deficiency in the other body stores. In the study by Marquis et $\mathrm{al}^{19}$ found that muscle mass is an even better predictor of mortality than body weight.

\section{Mid Arm Fat Area (MAFA)}

In this study the average MAFA of the population was $14.52+$ $4.93 \mathrm{~cm}^{2}$ (Table 1).12 (24\%) patients were in the bottom quartile ( $<25^{\text {th }}$ percentile) of the distribution and were found to have severe fat depletion. A significant difference was established in MAFA of the patients with severe and very severe airway obstruction when compared to those with mild and moderate airway obstruction. This study also showed a statistically significant and moderate positive correlation between decrease in MAFA and increase in severity of airway obstruction (correlation coefficient is 0.72 ) ( $r=0.72$ and $p<$ 0.0001). The severity of muscle mass depletion correlated more strongly with the severity of airway obstruction when compared to the severity of fat depletion. These findings are similar with study done by Soler JJ et al. ${ }^{4}$

\section{Measures of Visceral Protein Stores}

In this study measures of visceral protein stores such as serum albumin and pre-albumin were used.

\section{Serum Pre-Albumin}

The average pre-albumin value in the study population was $25.52+7.09 \mathrm{mg} / \mathrm{dL}$. An inverse correlation was found between the pre-albumin levels and the severity of airflow obstruction (with correlation coefficient is 0.81). A statistical significant difference was established in the mean pre-albumin values between severe and very severe groups and with mild and moderate groups of disease $(\mathrm{p}<0.0001)$. A strong, positive and significant correlation was found between severity of airway obstruction and decreased pre-albumin levels. Study by Toppo A et $\mathrm{al}^{20}$ demonstrated significant difference between severity of the disease and serum prealbumin levels $(\mathrm{p}<0.05)$. There was a significant and strong negative correlation between the COPD grading and serum pre-albumin $(r=-0.315$ and $\mathrm{p}=0.006)$.

\section{Serum Albumin}

The mean albumin value of the patients in the study was 3.67 $+0.30 \mathrm{gm} / \mathrm{dL}$. This study found a significant and inverse correlation between the severity of airway obstruction and albumin levels $(r=0.74)$. A statistical significant difference was established in the mean albumin values between severe and very severe and with mild and moderate airway obstruction ( $\mathrm{p}<0.001) .9(18 \%)$ out of 50 patients have a serum albumin of less than $3.5 \mathrm{gm} / \mathrm{dL}$. In Soler JJ et al ${ }^{4}$ study, 17 (9.6\%) patients have a serum albumin level less than 3.5 gm / dL. In Chaudhary SC et al ${ }^{13}$ study, A significant decrease in mean serum albumin levels with increasing severity of the disease was observed $(\mathrm{p}<0.001)$. In the study by $\mathrm{L}$ Yazdanpanah et $\mathrm{al}^{21}$ the mean albumin levels were significantly decreased with increase in the severity of disease $(p=0.000)$.

\section{CONCLUSIONS}

A significant number of patients with Chronic Obstructive Pulmonary Disease were malnourished. Measures of protein stores [serum albumin and pre-albumin] and the anthropometric measures of nutrition (BMI, body muscle mass and fat stores) were inversely related with severity of airway obstruction. 
Data sharing statement provided by the authors is available with the full text of this article at jemds.com.

Financial or other competing interests: None.

Disclosure forms provided by the authors are available with the full text of this article at jemds.com.

\section{REFERENCES}

[1] Lozano R, Naghavi M, Foreman $K$, et al. Global and regional mortality from 235 causes of death for 20 age groups in 1990 and 2010: a systemic analysis for the Global Burden of Disease Study 2010. Lancet 2012;380(9859):2095-128.

[2] Mathers CD, Loncar D. Projections of global mortality and burden of disease from 2002 to 2030. PLoS Med 2006;3(11): e442.

[3] Global Initiative for Chronic Obstructive Lung Disease. Global strategy for the diagnosis, management and prevention of chronic obstructive pulmonary disease. 2018.

[4] Soler JJ, Sanchez L, Roman P, et al. Prevalence of malnutrition in outpatients with stable chronic obstructive pulmonary disease. Arch Bronconeumol 2004;40(6):250-8.

[5] Bhakare MN, Godbole GP, Khismatrao DS, et al. Correlating nutritional status with severity of chronic obstructive pulmonary disease in adult females. Med J DY Patil Univ 2016;9(5):570-6.

[6] Vermeeren MAP, Creutzberg EC, Schols AMWJ, et al. Prevalence of nutritional depletion in large out-patient population of patients with COPD. Respir Med 2006;100(8):1349-55.

[7] Wagner PD. Possible mechanisms underlying the development of cachexia in COPD. Eur Respir J 2008;31(3):492-501.

[8] Schols AM. Nutrition in chronic obstructive pulmonary disease. Curr Opin Pulm Med 2000;6(2):110-5.

[9] Collins PF, Stratton RJ, Elia M. Nutritional support in chronic obstructive pulmonary disease: a systematic review and meta-analysis. Am J Clin Nutr 2012;95(6):1385-95.
[10] Olabinri BM, Olaleye TM, Akinola F, et al. Age- specific association between percent body fat and pulmonary function in apparently normal children in Ogbomoso, Ogo State, Nigeria. African J Biomed Res 2006;9(2):83-7.

[11] Doekel RC Jr, Zwillich CW, Scoggin CH, et al. Clinical semistarvation: depression of hypoxic ventilatory response. $\mathrm{N}$ Engl J Med 1976;295(7):358-61.

[12] Mathew JT, Veena GV, Kurpad AV, et al. Nutritional status predicts outcome in patients hospitalized with exacerbation of chronic obstructive pulmonary disease. Lung India 2006;23(4):143-6.

[13] Chaudhary SC, Rao PK, Sawlani KK, et al. Assessment of nutritional status in chronic obstructive pulmonary disease patients. International Journal of Contemporary Medical Research 2017;4(1):268-71.

[14] Calle EE, Thun MJ, Petrelli JM, et al. Body- mass index and mortality in a prospective cohort of US adults. N Engl J Med 1999;341(15):1097-105.

[15] Sami R, Sadegh R, Esmailzadehha N, et al. Association of anthropometric indexes with disease severity in male patients with chronic obstructive pulmonary disease in Qazvin, Iran. Am J Mens Health 2018;12(4):1023-8.

[16] Gupta B, Kant S, Mishra R, et al. Nutritional status of chronic obstructive pulmonary disease patients admitted in hospital with acute exacerbation. J Clin Med Res 2010;2(2):68-74.

[17] Matthews AL. Mid upper arm circumference in adults. Nutrition 1995;78:887-92.

[18] Moffatt RJ, Sady SP, Owen GM. Height, weight and skinfold thickness of Michigan adults. Am J Public Health 1980;70(12):1290-2.

[19] Marquis K, Debugare R, Lacasse Y, et al. Midthigh muscle cross-sectional area is better predictor of mortality than body mass index in patients with chronic obstructive pulmonary disease. Am J Respir Crit Care Med 2002;166(6):809-13.

[20] Toppo A, Sudheer D, Rajawat GS, et al. A study to assess nutritional profile in chronic obstructive pulmonary disease patients. Int J Adv Med 2017;4(2):450-6.

[21] Yazdanpanah L, Shidfar F, Moosavi JA, et al. Assessment of nutritional status in chronic obstructive pulmonary disease patients. Iranian J Publ Health 2009;38(3):39-45. 